\title{
Crafting Wounaan Landscapes: Identity, Art, and Environmental Governance in Panama's Darién. By Julie Velásquez Runk. 2017. University of Arizona Press, Tucson, AZ. 313 pp.
}

Editor's Note: This book has also just been published in Spanish, by Bogotá's Instituto Colombiana de Antropología e Historia with the title: Los wounaan y la construcción de su paisaje: Identidad, arte y gobernanza ambiental en la frontera PanamáColombia. 2020.

Katherine E. French ${ }^{1^{*}}$

${ }^{1}$ Department of Plant and Microbial Biology Koshland Hall, Berkeley, USA.

*katharine.e.french@gmail.com

Received August 23, 2020

OPEN ठACCESS

Accepted September 11, 2020

DOI 10.14237/ebl.12.1.2021.1727

Published February 1, 2021

Copyright (C) 2021 by the author(s); licensee Society of Ethnobiology. This is an open-access article distributed under the terms of the Creative Commons Attribution-NonCommercial 4.0 International Public License (https://creativecommons.org/licenses/by-nc/4.0), which permits non-commercial use, distribution, and reproduction in any medium, provided the original author and source are credited.

How does the environment shape cultural identity and how can this knowledge be used to inform conservation activities? Julie Velásquez Runk takes us on a unique journey to Panama's Darién, weaving together anthropology, history, and ecology to understand the central role of landscape to the Wounaan people and to argue for a more culturally conscious form of biodiversity management. The Wounaan people live along the Chucunaque, Sambú, and Tuira Rivers; their livelihoods are based on a mix of subsistence fishing, swidden agriculture, and crafts (mainly baskets and tagua figurines) made from forest products. Velásquez Runk has a unique expertise on the area; she previously conducted conservation work in the region (1996-2001) followed by two stints of ethnographic fieldwork (2001-2005 and 2006-2016). This experience of both the land and people make her an expert on the subject and lends nuance to her calls to shift conservation practices in the region.

Chapters 1 and 2 provide historical and geographic background to the region. Archaeological evidence suggests that indigenous people have occupied the area for at least 3,800 years, cultivating maize (Zea mays) and practicing swidden agriculture, until subsequent occupation by the Spanish 350 years ago changed the region. Population levels declined and the Panama Canal region became a hotspot for international trade in gold and minerals from South
America, culminating in the creation of the Panama Canal many years later. It is this political and social climate of military action, trade, and cultural mixing, that forms the backdrop to Velásquez Runk's study.

Chapter 3 focuses on indigenous cosmologies/ ontologies, which revolve around local riverways, which are used for social exchanges, trade, and are the home to local spirits. Images of riverine wildlife decorate local basketry and carvings, reinforcing the importance of these landscapes. In Wounaan culture, landscapes are marked by their own topography of spirits: they inhabit different ecosystems but also organic and inorganic objects, and can affect those who come in contact with them both negatively and positively. The result of this worldview is a charged landscape. Where outsiders might view an empty, silent forest, the Wounaan view the same space as teeming with spirits.

Chapters 4 and 5 focus on forest use and craft traditions. Many indigenous carvings are made of Cocobolo (Dalbergia sp.), a tropical rosewood that produces heavy, hard wood in multiple colors. Artisans primarily use roots and branches from fallen trees, preserving the living forests where possible. In the past artisans mostly created domestic objects (e.g., tools and utensils) but have shifted to pieces that might appeal to tourists (e.g., animal sculptures) in recent years. The Wounaan are also known for their 
basketry, which are made from the fibers of the chunga or black palm (Astrocaryum standleyanum). These goods are an important source of income where informal wage labor is scarce. Wounaan young men also collect the seeds from the tagua palm to produce carvings of local wildlife (e.g., hummingbirds) for tourists. Finally, Chapter 6 delves into scientific paradigms and political motivations driving conservation activities in the region and how indigenous communities have used international conservation paradigms like REDD+ (Reducing Emissions from Deforestation and Forest Degradation) to express their agency in managing and using their local landscape/natural resources. The text is rich in Wounaan language and contains a glossary of terms at the end of the book. Numerous black and white photos of the landscape and inhabitants complement the text and give the reader a sense of place.

Velásquez Runk's book touches upon a topic not usually covered in conservation: the role of indigenous ontologies in setting conservation priorities and managing landscapes with both local and global importance. The anthropological study of ontology focuses on how world views are constructed, expressed and passed on from generation to generation. In the case of the Wounaan, myths about the surrounding forests and rivers shape their ontologies of life, health and community and permeate their art. How they conceive, value, and engage with the natural world is intimately connected to these beliefs. Velásquez Runk notes that conservation objectives are often driven by scientific goals (preserving biodiversity) or political agendas (controlling access to land/resources). This process has the potential to disenfranchise the people who inhabit these landscapes; it also threatens their identity, culture, and livelihoods. Velásquez Runk demonstrates that integrating indigenous ontologies can help direct which resources are protected and how in a manner that benefits local communities as well as conservationists. This echoes the work of other anthropologists who note integrating ontology into conservation can strengthen local adoption of and active participation in conservation polices (Fernández-Llamazares and Cabeza 2018; Schroeder and González 2019), develop more nuanced conservation programs based on local ecological knowledge (Rist and Dahdouh-Guebas 2006), and promote indigenous decision-making authority and self-governance while decolonizing environmental management (Muller et al. 2019).

Overall, this book would appeal to those interested in Central and South American ethnobiology and new ways of conducting conservation.

\section{References Cited}

Fernández-Llamazares, Á., and M. Cabeza. 2018. Rediscovering the Potential of Indigenous Storytelling for Conservation Practice. Conservation Letters 11:e12398. DOI:10.1111/conl.12398.

Muller, S., S. Hemming, and D. Rigney. 2019. Indigenous Sovereignties: Relational Ontologies and Environmental Management. Geographical Research 57:399-410. DOI:10.1111/1745-5871.12362.

Rist, S., and F. Dahdouh-Guebas. 2006. Ethnosciences-A Step Towards the Integration of Scientific and Indigenous Forms of Knowledge in the Management of Natural Resources for the Future. Environment, Development and Sustainability 8:467-493. DOI:10.1007/s10668-006-9050-7.

Schroeder, H., and N. C. González. 2019. Bridging Knowledge Divides: The Case of Indigenous Ontologies of Territoriality and REDD+. Forest Policy and Economics 100:198-206. DOI:10.1016/ j.forpol.2018.12.010. 